\title{
ANALYSIS OF GENDER DISAGGREGATED VEGETABLES VALUE CHAIN IN YAYU AND HURUMU DISTRICTS, ILLUABABORA ZONE, ETHIOPIA
}

\author{
Banchamlak Hegena (M.sc) \\ Department of Agribusiness and Value Chain \\ Management, College of Agriculture and Natural \\ Resource, Wolkite University, Ethiopia
}

\begin{abstract}
This study aimed at Analyzing gender disaggregated vegetables value chain in Yayu and Hurumu districts of Illuababora zone, south west Ethiopia with specific objectives of examining the role of men and women in the vegetables value chain and assessing distribution of benefit among actors in vegetable value chain. The primary data for this study were collected from 117 cabbage and onion farmers, 37 traders and 31 consumers through appropriate statistical procedures. The study shows that both men and women are involved in vegetables production and marketing activities through $\mathbf{8 8 \%}$ of the marketing of vegetables were done by women. The value chain analysis reveals that the major actors in the districts are input problem and lack of government support as the major problems. The reason could be low production habit and small land allocation for vegetables and institutional weakness. Average shares of profit of local collectors, wholesalers and retailers were $29.3 \%, 42.5 \%$ and $12.7 \%$ and $23.5 \%, 34 \%, 10.1 \%$ in male and female actors, respectively, from the sales of one kilogram cabbage. This reveals that wholesalers benefited more than other actors. Average shares of profit of wholesalers and retailers were $18.8 \%$ and $29.6 \%$ and $18.2 \%, 28.6 \%$ in male and female actors, respectively, from the sales of one kilogram onion. This asserts that retailers benefit more than other actors. Therefore, policy aiming at improving actors access to improved extension service and empower women to enhance vegetable value chain in study area is crucial empower women to enhance vegetable value chain in study area is crucial.
\end{abstract}

Keywords: Actors, Gender, Value chain, Vegetables, Yayu and Hurumu.

\author{
Adugna Eneyew (PhD. Candidate) \\ Department of Rural Development, College of \\ Agriculture and Veterinary Medicine, Jimma \\ University, Ethiopia.
}

\section{INTRODUCTION}

Agriculture is the mainstay of Ethiopian economy contributing about $40 \%$ of the GDP, $72.7 \%$ of employment and $81 \%$ of the export (UNDP, 2015). Horticultural crops play a significant role in Ethiopia, both in income and social spheres for improving income and nutrition status. Further, it provides employment opportunities as their management being labour intensive, and Ethiopia is a labour abundant and capital scarce country. Demand for horticultural products tends to grow very rapidly with urbanization and increased income. Ethiopia earns around (US\$45.9 million) from fruit and vegetables exports in 2013/14 (EIC, 2015).

Vegetables are sources of vitamins, minerals and income for those involved in production and marketing. Its production gives an opportunity for intensive production and increases male and female farmer's participation in the market (Emana and Gebremedihin, 2007). In Ethiopia, the area under these crops (vegetables and root vegetables) was estimated to be 356688.2; hectares with a total production of 60569544.25 Qt in the year 2014/15. Vegetables took up about $0.98 \%$ of the area under all crops at national level (CSA, 2015).

Rural women in Ethiopia represent a tremendous productive resource in the agricultural sector. In comparison to men, women are major contributors to the agricultural workforce, either as family members or in their own right as women heading households. However, despite many recent initiatives, a mixture of economic constraints, cultural norms and practices continue to limit women's contribution to household food security and, to a lesser extent, inhibit the commercialization of the sector (PASDEP, 2005). 


\section{International Journal of Engineering Applied Sciences and Technology, 2020 \\ Vol. 4, Issue 10, ISSN No. 2455-2143, Pages 287-298 \\ Published Online February 2020 in IJEAST (http://www.ijeast.com)}

Specific to the study areas in $2014 / 15$ production year, $173,064.00$ smallholder farmers were engaged in vegetable production, and1,069,692.39Qt of vegetables were produced in Illuababora Zones (CSA, 2015).Vegetable production has significant contribution in supporting household income and used as source of food in both districts. In these two districts, different vegetables are grown with different intensities depending on environmental condition and level of marketability.

Analyses of gender disaggregated vegetable value chain are vital to improve the vegetable value chain. It has a significant role in improving household income, nutrition and food security. Despite the enormous merits and potentials, there is no empirical evidence to inform agricultural practitioners in the study areas on the role of gender in the vegetable value chain and benefit distribution of actors in study areas.

\section{Objectives of the study}

The general objective of the study is to analyze vegetables value chain in gender perspective in the study areas.

The specific objectives of the study were;

1. To examine the roles of men and women in vegetables production and marketing.

2. To assess distribution of benefit among actors in vegetable value chain.

\section{METHODOLOGY OF THE STUDY}

\section{Description of Study Areas}

Yayu and hurumu District: Two of the districts in the Illuababora zone of Oromia region. Yayu forest is recently registered by the government of Ethiopia as United Nations Educational, Scientific and Cultural Organization (UNESCO) biosphere reserve sites for biodiversity conservation including wild coffee gene pools. (YW, 2016).

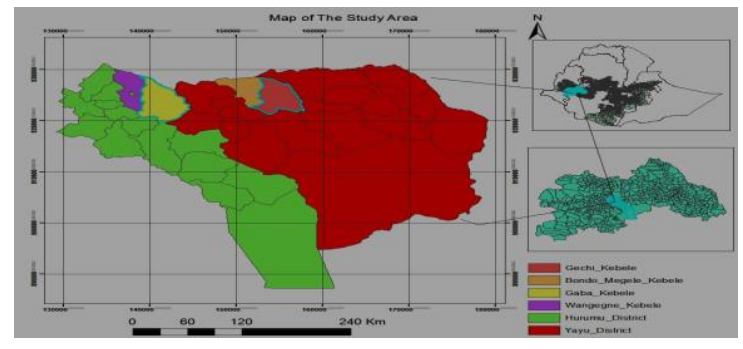

Figure: 1. Geographical location of the study areas Source: GIS. Sketch by Getinet Seid.

\section{Types, Sources and Methods of Data Collection}

The study collected data on different variables, demographic and socioeconomic characteristics like (age, education level, gender, occupation household income, and transport material ownership), institutional factors like (access to credit, access to extension service and road infrastructure) and market factors like (prices of output, market information, marketing experience, and distance to the market). Survey was made to obtain this information. The study was requiring both qualitative and quantitative data and demand information from different sources of primary and secondary databases. Primary data were collected by using surveys. The survey was undertaken through formal interviews with sample farmers (male and women) and in addition data from sampled traders, support service providers, and consumers was collected using semi- structured questionnaire through Key Informant Interview and Focus Group Discussions. The secondary data sources were documents of published/unpublished reports, websites and articles

\section{Sampling Procedure and Sample Size Determination} This study site was chosen by NutriHAF project. As Yayu and Hurumu districts were the two NutriHAF implementation district in south west Ethiopia. The two districts were selected purposively based on the aim of the project. Based on the objectives of the project, it was implemented on two kebeles in Yayu and two kebeles in Hurumu districts. Therefore, this study was based on preselected four kebeles from the two districts.

Table 1: Sampling frame

\begin{tabular}{|c|c|c|c|c|c|c|}
\hline \multirow{2}{*}{$\begin{array}{l}\text { Distri } \\
\text { ct }\end{array}$} & \multirow{2}{*}{$\begin{array}{l}\text { Select } \\
\text { ed } \\
\text { kebele } \\
\mathrm{s}\end{array}$} & \multirow{2}{*}{$\begin{array}{l}\text { Veg } \\
\text { etab } \\
\text { le } \\
\text { prod } \\
\text { ucer } \\
\text { s }\end{array}$} & \multirow{2}{*}{$\begin{array}{l}\text { Proport } \\
\text { ion }\end{array}$} & \multicolumn{2}{|c|}{ Sampled No. } & \multirow[t]{2}{*}{ Total } \\
\hline & & & & $\begin{array}{l}\text { Male } \\
\text { farm } \\
\text { ers }\end{array}$ & $\begin{array}{l}\text { Fem } \\
\text { ale } \\
\text { farm } \\
\text { ers }\end{array}$ & \\
\hline Yayu & Gechi & 745 & 0.33 & 22 & 17 & 39 \\
\hline & $\begin{array}{l}\text { Bond } \\
\text { o } \\
\text { Megel } \\
\text { a }\end{array}$ & 536 & 0.23 & 15 & 12 & 27 \\
\hline Huru & Gaba & 526 & 0.23 & 14 & 13 & 27 \\
\hline $\mathrm{mu}$ & $\begin{array}{l}\text { Wang } \\
\text { egne }\end{array}$ & 480 & 0.21 & 13 & 11 & 24 \\
\hline Total & & $\begin{array}{l}228 \\
7\end{array}$ & 1 & 64 & 53 & 117 \\
\hline
\end{tabular}

To develop sampling frame for vegetable producer of selected rural kebeles three stage sampling technique were employed. In the first stage by consultation with DAs of the selected kebeles the respective farmers were stratified 


\section{International Journal of Engineering Applied Sciences and Technology, 2020 \\ Vol. 4, Issue 10, ISSN No. 2455-2143, Pages 287-298 \\ Published Online February 2020 in IJEAST (http://www.ijeast.com)}

as vegetable producers and non-producers. In second stage of sampling procedure, the sampling frame was stratified as male and female farmers. Finally, sample farmers were selected randomly based on proportional to the population size from the selected kebeles (Table1). To identify the respondent random lottery method was applied on fresh list of vegetable growers.

The sample size was 117 respondents (53 females, 64 males) who were selected from the 2 kebeles in Yayu and 2 kebeles in Hurumu districts based on proportional to the population size of vegetable producers. This sample size was determined by using Yamane (1967) formula.

In addition to the purpose of the study and population size, three criteria usually were needed to be specified to determine the appropriate sample size: the level of precision (e), the level of confidence or risk (Z), and the degree of variability $(p)$ in the attributes being measured (Miaoulis and Michener, 1976). Sampling technique was used to determine a sample size of the respondents by using Yamane (1967) formula with a confidence level of $95 \%$, degree of variability $5 \%$ and $9 \%$ of level of precision.

$n=\frac{N}{1+N(e)^{2}}$

$\mathrm{n}=$ sample size

$\mathrm{N}=$ total number of vegetable producer of selected kebeles $\mathrm{e}=9 \%$ level of precision

$$
n=\frac{2287}{1+2287(0.09)^{2}}=117
$$

\section{Traders sampling}

For this study, data from traders and consumers were also collected. The sites for the trader surveys were market towns in which a good sample of vegetable traders existed. The lists of wholesalers were obtained from the respective District Office of Trade and Market Development (DOoTMD) and for other traders there is no recorded list. From 5 wholesalers, all of them were interviewed. In addition, 30 retailers and 2 collectors were randomly selected constituting a total of 37 traders from Yayu and Hurumu markets. Furthermore, 31 consumers were interviewed from both districts, which were selected purposively to obtain information related to consumers (Table 2).

Table 2: Sample distribution of traders and consumers of vegetables

\begin{tabular}{|c|c|c|c|c|c|}
\hline \multirow[t]{3}{*}{ Traders } & \multicolumn{2}{|l|}{ Yayu } & \multicolumn{2}{|c|}{ Hurumu } & \multirow{3}{*}{$\begin{array}{l}\text { Tota } \\
1\end{array}$} \\
\hline & Male & Female & Male & Female & \\
\hline & $\mathrm{s}$ & $\mathrm{s}$ & $\mathrm{s}$ & $\mathrm{s}$ & \\
\hline Wholesaler & 2 & 1 & - & 2 & 5 \\
\hline
\end{tabular}

\begin{tabular}{llllll}
\hline S & & & & & \\
Retailers & 1 & 15 & 1 & 13 & $\mathbf{3 0}$ \\
Collector & 1 & & & 1 & $\mathbf{2}$ \\
Consumers & 4 & 12 & 3 & 12 & $\mathbf{3 1}$ \\
\hline
\end{tabular}

Source: Own survey results, 2018.

\section{Methods of data analysis}

Descriptive statistics

Data from the field were edited, coded, and cleaned to ensure consistency, uniformity, and accuracy and analyzed by using both SPSS version 20 and STATA version 13. Maps were used to analyze the survey data collected from smallholder vegetable farmers, collectors/assemblers, wholesalers, retailers and consumers.

Analysis of the role of gender in vegetable value chain at producer level Harvard Analytical Framework is a gender framework tool, which was used to analysis the role of gender and their constraints along vegetable value chain.

\section{Estimation of benefit distribution of actors in market chain \\ Total Gross Marketing Margin (TGMM)}

According to Mendoza (1995) the total gross marketing margin was done by using the following formula. Computing the Total Gross Marketing Margin (TGMM) is always related to the final price paid by the end buyer and is expressed as a percentage.

$\mathrm{TGMM}=\left(\frac{\text { Consumer price-Producer price }}{\text { Consumer Price }}\right) \times 100$

\section{Net Marketing Margin(NMM)}

Net Marketing Margin (NMM) is the percentage over the final price earned by the intermediary as his net income once his marketing costs are deducted. The equation tells us that a higher marketing margin diminishes the producer's share and vice-versa. It also provides an indication of welfare distribution among production and marketing agents.

$\mathrm{NMM}=\left(\frac{\text { Gross Marketing Mar-Marketing cost }}{\text { consumer price }}\right) * 100$

From this measure, it is possible to see the allocate efficiency of markets. Higher NMM or profit of the marketing intermediaries reflects reduced downward and unfair income distribution, which depresses market participation of smallholders. An efficient marketing system is the net margin is near to reasonable profit (Tegegn, 2013). 


\section{International Journal of Engineering Applied Sciences and Technology, 2020 \\ Vol. 4, Issue 10, ISSN No. 2455-2143, Pages 287-298 \\ Published Online February 2020 in IJEAST (http://www.ijeast.com)}

To find the benefit of each actor the same concept was applied with some adjustments. In analyzing margins, first the Total Gross Marketing Margin (TGMM) was calculated. This is the difference between producer's (farmer's) price and consumer's price (price paid by final consumer) i.e. Gross Marketing Margin (GMM).

$G M M=\frac{\text { Consumer price-Producer price }}{\text { Total Gross Marketing Margin }} * 100$

\section{RESULT AND DISCUSSION}

\section{Gender role in vegetable value chain}

Production of vegetables is a labour intensive enterprise; it involves a variety of function such as land preparation, ploughing, sowing seeds in a nursery bed, transplanting, irrigating, weeding and harvesting, transporting and storage before sale. Most farmers do not have adequate family labour, thus they usually employ daily workers, who are paid in cash.

Table 3: Gender in vegetable production and marketing

\begin{tabular}{|c|c|c|c|c|c|c|c|c|}
\hline Activities & $\begin{array}{l}\text { Men } \\
(\%)\end{array}$ & $\begin{array}{l}\text { Women } \\
\text { \%) }\end{array}$ & $\begin{array}{l}\text { Mainly } \\
\text { Men } \\
(\%)\end{array}$ & $\begin{array}{l}\text { Mainly } \\
\text { Women } \\
(\%)\end{array}$ & $\begin{array}{l}\text { Both } \\
\text { equally } \\
(\%)\end{array}$ & $\begin{array}{l}\text { Boys } \\
(\%)\end{array}$ & $\begin{array}{l}\text { Girls } \\
(\%)\end{array}$ & $\chi^{2}$-test \\
\hline Ploughing & 85.5 & & 1.7 & & & 12.8 & & 0.945 \\
\hline Sowing & 15.4 & 64.1 & & 2.6 & 17.9 & & & $6.59 *$ \\
\hline $\begin{array}{l}\text { Applying } \\
\text { fertilizers }\end{array}$ & 12 & 70.9 & & 0.9 & 16.2 & & & 6.17 \\
\hline Weeding & - & 63.2 & & 2.6 & 18.8 & 5.1 & 10.3 & 7.09 \\
\hline Watering & 9.4 & 65.8 & & 1.7 & 18.8 & 2.6 & 1.7 & $11.06^{*}$ \\
\hline Harvesting & 14.5 & 64.1 & & 1.7 & 18.8 & & 0.9 & $10.5^{* *}$ \\
\hline Transporting & 1.7 & 86.3 & & & 6.8 & & & 1.84 \\
\hline Storing & 0.9 & 78.6 & & 2.6 & 17.9 & & & $8.76 * *$ \\
\hline Marketing & & 88 & & & 12 & & & $3.27 *$ \\
\hline
\end{tabular}

Source: Own computation from survey result, 2018.

Table: 3 depicted above realize that most of the activities in vegetable value chain performed by women. Activities such as sowing, watering, harvesting, storing and marketing are statistically significant at 5\% and $10 \%$ probability. Men, women and children are involved in different vegetables production activities. Some activities are mostly done by women only while others are done by men; almost all activities are done by women. During this study it was reported that ploughing is mostly done by men $(85.5 \%)$. There are some activities which were reported to be done mostly done by women e.g. Watering $65.8 \%$ for women versus $9.4 \%$ by men only and harvesting of vegetables where $64.1 \%$ were done by women and $14.5 \%$ by men, marketing of vegetables $88 \%$ were done by women. It is believed that women are highly gifted with marketing skill. Women sell vegetable to buy consumable goods like oil, soap, sugar and others. On average, women visit market two times per week (Durr, 2016). Children are also involved in vegetable production activities especially in weeding; boys $(5.1 \%)$ and girls $(10.3 \%)$ of these activities were done by children.
Gendered participation and control over resources in the value chain

Based on semi-structured interviews as well as observations, the results show that, marketing of vegetables dominated by women, particularly within the functions of retailing (Figure 2:). Majority of the retailers at the markets are women who trade with low volumes of vegetables. The wholesalers interviewed also asserted that local collectors are young men and women. Men are perceived to dominate the positions as collectors, although respondents asserted that women were also engaged in wholesale. Respondents of the surveyed households selling vegetables said that the buyers of their products were dominantly women.

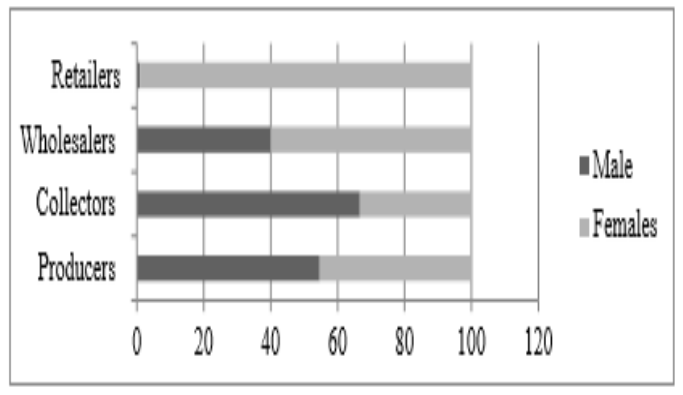

Figure 2: Gendered participation in the vegetables value chain nodes

Source: Sketch from survey result, 2018.

\section{Control over Resources}

It has been argued that gender analysis enhances the understanding of not only the practical needs but also the strategic needs of women farmers. It shows that it is not only a question of whether women farmers have access to key inputs but also whether they have control over resources and benefit(Anteneh, 2008).

The pattern of decision making varies from one place or culture to another. In some areas, households fit the standard model of a single decision maker. Here the household head, in most cases men, are the sole decision makers in the household. In other areas, household decision are shared, consultation takes place between particular members or all members. In some areas, however household members have wholly separate spheres of decision making affecting production, income and expenditure (Feidstein and Poats, 1989).

Table 4: Women's Participation in Decisions Related to Production

Decision on house hold Yes No 
International Journal of Engineering Applied Sciences and Technology, 2020

Vol. 4, Issue 10, ISSN No. 2455-2143, Pages 287-298

Published Online February 2020 in IJEAST (http://www.ijeast.com)

\begin{tabular}{lll}
\hline land & & \\
\hline How much land to plant & 70.3 & 29.7 \\
Crop type & 75 & 25 \\
To share the land & 67.2 & 32.8 \\
Land rent & 45.3 & 54.7 \\
Fertilizers use & 65.6 & 34.4 \\
Hiring labor & 67.2 & 32.8 \\
\hline
\end{tabular}

Source: Own computation from survey result, 2018.

The study found that wives participated in most of these issue they were found to participate in deciding how much land to plant 70.3 per cent of farm households. This shows that they were exercising decision making power in their farm land as they jointly own the farm land and as they were major actors in the farm production. Similarly, 75 per cent of them actively participated in decisions related to what type of crops to plant during the planting seasons (Table 4).

\section{Value Chain Analysis}

\section{Value chain map of vegetables in Yayu and Hurumu} districts

Value chain mapping enables to visualize the flow of the product from conception to end consumer through various actors. It also helps to identify the different actors involved in the vegetable value chain, and to understand their roles and linkages. It is made up of three inter linked components namely value chain actors enabling environment and service providers. The value chain actors are those directly involved in value chain activities. These are input Suppliers, producers, traders and consumers. The enabling environment is activities related to infrastructure and policies that shape production and market environments. The service providers are those who provide services such as transportation, extension service, credit, information, etc that support the value chain.

\section{Actors and their role in vegetable value chain}

The value chain map highlighted the involvement of diverse actors who are participated directly or indirectly in the value chain. The direct actors are those involved in commercial activities in the chain (input suppliers, producers, traders, consumers) and indirect actors are those that provide financial or non-financial support services, such as credit agencies, business service providers, government, NGOs, cooperatives and extension agents(KIT et al., 2006).

\section{Primary actors}

The primary actors in vegetable value chain in Yayu and Hurumu districts were seed and other input suppliers, farmers, traders and consumers. Some functions or roles are performed by more than one actor and some actors perform more than one role.

\section{Input Suppliers}

At this stage there are many actors who are involved directly or indirectly in agricultural input supply in the study areas. Agriculture office, Irrigation development office, primary cooperatives, private input suppliers and NGOs are the main source of input supply. Wetland is also participates in this stage for seed supply. All such actors are responsible to supply agricultural inputs like improved seed varieties, fertilizers, herbicides and pesticides which are essential inputs at the production stage. For major vegetable produced in Yayu and Hurumu districts, majority of sample producer accessed seed from illegal market. Regarding fertilizers, some farmers used only organic fertilizer (manure) while some farmers used both inorganic and organic fertilizers depending on the land size allocated to vegetable.

\section{Producer}

Producers are actors who cultivate and supply vegetable to market and perform most of the value chain functions. The major value chain functions that vegetable growers perform include land preparation, ploughing, planting, fertilizer application, irrigating, weeding, pest/disease controlling, harvesting and post-harvest handling. Vegetables production in these two districts was based on rain fed and irrigation system. In study areas $45.3 \%$ male and

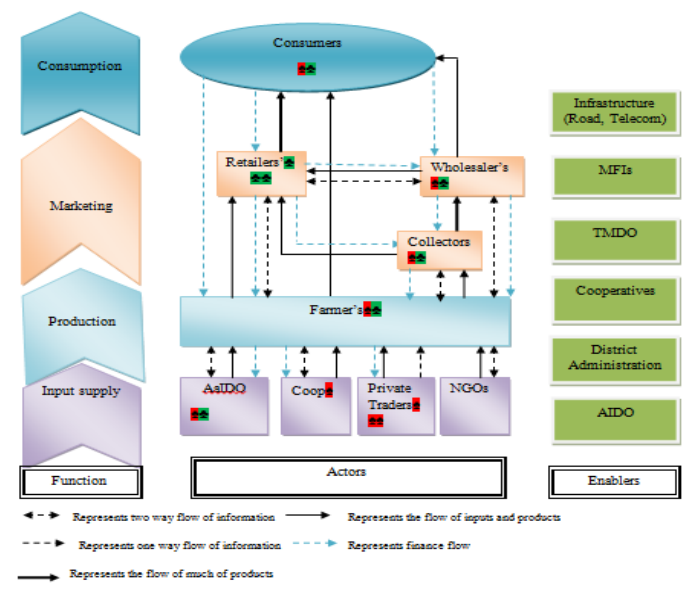

Figure 3: Vegetable Value Chain map in Yayu and Hurumu Districts ( $\alpha=$ Male, $=$ Female dominated areas). Source: Own sketch from survey result, 2018.

\section{Collectors/Assemblers}




\section{International Journal of Engineering Applied Sciences and Technology, 2020 \\ Vol. 4, Issue 10, ISSN No. 2455-2143, Pages 287-298 \\ Published Online February 2020 in IJEAST (http://www.ijeast.com)}

Collectors are traders who collect vegetables from farmers at farm get for the purpose of reselling it to wholesalers and retailers. They use their financial resources and their knowledge to collect vegetables from the surrounding area. Collectors are trading 82.6 and 33 quintals of cabbage from sample male and female farmers, respectively from production areas to wholesale and retail markets in the study areas.

\section{Wholesalers}

These are well-known for purchase of bulky commodities with better financial and information capability. In the study areas there were 5 wholesalers of which 2 were male and 3 of them were female wholesalers. They purchase vegetable either directly from farmer or collectors. They buy large amount of vegetables to Yayu and Hurumu market. In study areas wholesale markets are the main assembly centers for vegetables in their respective surrounding areas. They have better storage and communication access than other traders. They are located in Yayu and Hurumu towns.

\section{Retailers}

These are the most important actors in vegetables value chain in both districts and they are known for their limited capacity of procuring and handling produces with low financial and information capability. In addition, these are the final actors in the market chain that buy and deliver vegetables to consumers. In Yayu and Hurumu districts female retailers were dominated the vegetables market about 99.1percent were female retailers.

\section{Consumer}

Consumers are those purchasing vegetables for consumption. About three types of vegetable consumers were identified: households, hotel and restaurants and institutions like fertilizer factory. Private consumers purchase vegetables directly from producers, retailers and wholesalers though most of the consumers purchase from retailers. Private, hotel and restaurants purchase and consume vegetables with an average income of ETB 4531.3 and 3153.3 per month and private consumers purchase vegetables by $21.8 \%$ and $7.2 \%$ of their incomes in Yayu and Hurumu districts, respectively.

Private, hotel and restaurants consumers purchase vegetables directly from producers, retailers and wholesalers though most of the consumers purchase from producers and retailers. The survey result also showed that, on average $3.3 \mathrm{~kg}$ of cabbage and $1.9 \mathrm{~kg}$ of onion were consumed per week by private consumers.
Institution like fertilizer factory purchase vegetables product from wholesaler who has the capacity to supply sustainably based on contractual agreements. Consumers prefer dry, big, red color, a lot of leaf and not attack by insect onion and free from insect attach, big and medium, fresh, and clean cabbage. In general consumers have their own quality criteria to purchase vegetables.

\section{Supporting actors}

These actors are those who provide supportive services including training and extension, information and financial services. In vegetables value chains, the most important service providers were agriculture offices, irrigation development office, trade and marketing offices, cooperatives offices, financial institutions, NGOs, etc. They provided extension services, trainings, market information and credit.

\section{Access to Services}

Extension agents also provided training on new varieties, pest and disease control, soil and water management, and output marketing. The primary cooperatives provided agricultural inputs. DOoTMD registering the traders. The most important sources of market information for farmers were neighbor farmers, relative farmers and traders.

\section{Financial services}

In the study area, Oromia Credit and Saving Institution (OCSI) or (WALQO), WASASA and individual lenders have been identified as a potential source for credit both in kind or on a cash basis.

\section{Marketing Channels and Performance Analysis}

Marketing channels analysis describes the direction and volume of goods and services flow from producers to consumers. Cabbage and onion marketing channels were analyzed based on their direction and volume of flow.

\section{Cabbage marketing channel}

Seven main alternative channels were identified for cabbage marketing. The major actors in the channels were producers, collectors, wholesalers, retailers and consumers. From the total quantity marketed 708.6Qt of cabbage was supplied by sample respondents. Of this453.6Qt were supplied by sample male and 254.95Qt by female farmers. Figure 4 shows that the main receivers from producers were collectors, wholesalers, retailers and consumers with an estimated percentage share of, $16.3 \%, 8.3 \%, 42.6 \%$ and $32.8 \%$, respectively. According to volume of cabbage passed to different channels, the channel of producer retailer - consumer carry the largest volume followed by 


\section{International Journal of Engineering Applied Sciences and Technology, 2020 \\ Vol. 4, Issue 10, ISSN No. 2455-2143, Pages 287-298 \\ Published Online February 2020 in IJEAST (http://www.ijeast.com)}

producer- Consumer that carry a volume of $199.5 \mathrm{Qt}$ and 102.4Qts and 117.5Qtsand 114.5 in male and female farmers respectively.

\section{Financial services}

In the study area, Oromia Credit and Saving Institution (OCSI) or (WALQO), WASASA and individual lenders have been identified as a potential source for credit both in kind or on a cash basis.

\section{Marketing Channels and Performance Analysis}

Marketing channels analysis describes the direction and volume of goods and services flow from producers to consumers. Cabbage and onion marketing channels were analyzed based on their direction and volume of flow.

\section{Cabbage marketing channel}

Seven main alternative channels were identified for cabbage marketing. The major actors in the channels were producers, collectors, wholesalers, retailers and consumers. From the total quantity marketed 708.6Qt of cabbage was supplied by sample respondents. Of this453.6Qt were supplied by sample male and 254.95Qt by female farmers. Figure 4 shows that the main receivers from producers were collectors, wholesalers, retailers and consumers with an estimated percentage share of, $16.3 \%, 8.3 \%, 42.6 \%$ and $32.8 \%$, respectively. According to volume of cabbage passed to different channels, the channel of producer retailer - consumer carry the largest volume followed by producer- Consumer that carry a volume of $199.5 \mathrm{Qt}$ and 102.4Qts and 117.5Qtsand 114.5 in male and female farmers respectively.

Table 5: Cabbage marketing channel

\begin{tabular}{|c|c|c|}
\hline $\begin{array}{l}\text { Wedua Direction offlow } \\
\text { mel }\end{array}$ & $\begin{array}{l}\text { Volime offarom in } \\
\text { MF in Qts. }\end{array}$ & $\begin{array}{l}\text { Volume offlorr } \\
\text { infFin ints. }\end{array}$ \\
\hline 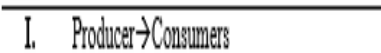 & 117.5 & 1114.55 \\
\hline II. Producer tRetalerst consimer & 199.5 & 1024 \\
\hline 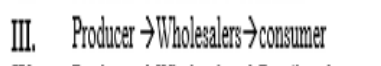 & 21 & 2 \\
\hline 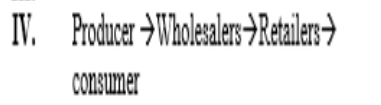 & 33 & 3 \\
\hline 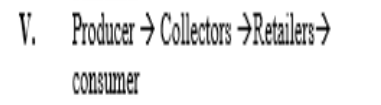 & 12.4 & 9 \\
\hline $\begin{array}{l}\text { VI. Producer } \rightarrow \text { Collectors } \rightarrow \text { tholeseders } \rightarrow \\
\text { consumer }\end{array}$ & 20.1 & 11 \\
\hline 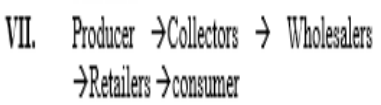 & 30.1 & 13 \\
\hline
\end{tabular}

Source: own sketch from survey result, 2018.

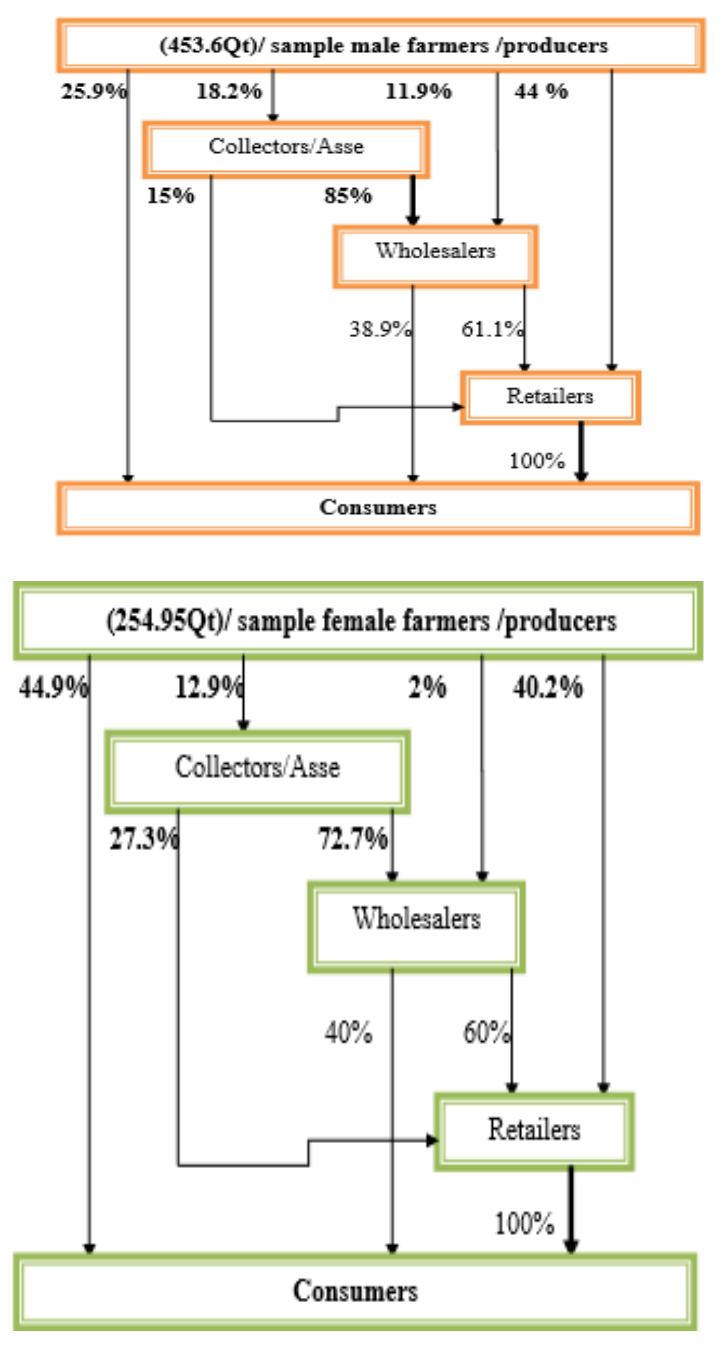

Figure: 4. Cabbage market channel Source: own sketch from survey result, 2018. Onion marketing channel

Four main alternative channels were identified for onion marketing. The major actors in the channels were producers, wholesalers, retailers and consumers. From the total quantity marketed 212.05Qt of onion was supplied by sampled farmers, of which $139.375 \mathrm{Q}$ t were supplied by sample male and 72.675 Qt by female farmers. Figure 5 shows that the main receivers from producers were wholesalers, retailers and consumers with an estimated percentage share of, $11.8 \%, 57.6 \%$ and $30.6 \%$, respectively. According to volume of onion passed to different channels, the channel of producer - retailer consumer carry the largest volume followed by producerConsumer that carry a volume of $90.125 \mathrm{Qt}$ and $32.02 .5 \mathrm{Qt}$ and $31.75 \mathrm{Qt}$ and $33.15 \mathrm{Qt}$ in male and female farmers, respectively. 
Table 6: Onion marketing channel

\begin{tabular}{|c|c|c|c|}
\hline Mcharnel & Direction of flow & $\begin{array}{l}\text { Volume of flow } \\
\text { in MF in Qt }\end{array}$ & $\begin{array}{l}\text { Volume of flow } \\
\text { in FF in Qt }\end{array}$ \\
\hline I. & Producert $\rightarrow$ Consumers & 31.75 & 33.15 \\
\hline II. & Producer $\rightarrow$ Retaliers $\rightarrow$ consumer & 90.125 & 32.025 \\
\hline III. & $\begin{array}{l}\text { Producer } \rightarrow \text { Wholesalers } \rightarrow \text { Retailers } \rightarrow \\
\text { consumer }\end{array}$ & 12.41 & s \\
\hline IV. & Producer $\rightarrow$ Wholesalers $\rightarrow$ consumer & 5.09 & 2.5 \\
\hline
\end{tabular}

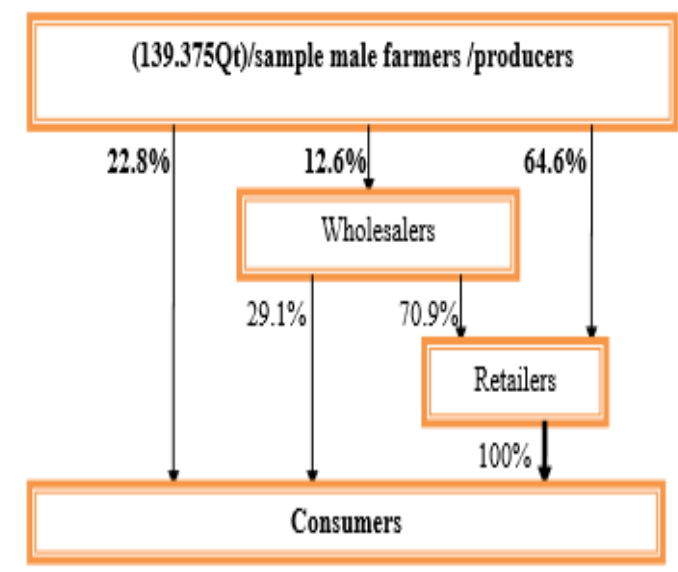

(72. 675 Qt)/sample female farmers /producers

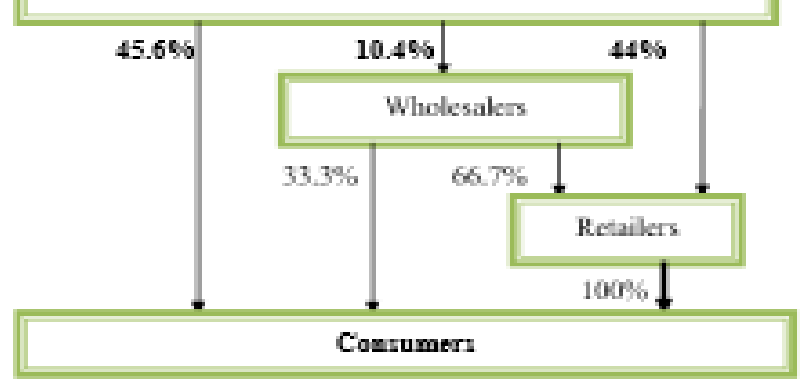

Figure 5: onion marketing channel.

Source: own sketch from survey result, 2018.

\section{Performance of vegetables market}

Performance of vegetables market was analyzed using costs (production and marketing costs), marketing margins and returns. Marketing margin used to measure the share of the final selling price that is captured by a particular actor in the value chain. Marketing margins were computed for producers, collectors, wholesalers and retailers.

Cabbage market performance
Marketing costs and benefit share of actors in cabbage value chain. Table 7 and 8 indicates different types of marketing cost related to the transaction of cabbage by producers, collectors, wholesalers and retailers and the benefit share of each marketing actors. Production costs such as seeds, fertilizers and labour were computed. As most of households used their own family labour, oxen and land, opportunity costs were used to compute costs of production. Accordingly, average cost of cabbage production for a sample farmer was 195ETB/Qt. Actors in cabbage value chain incurred marketing costs for transportation, packing, loading and taxes. Marketing margin used to measure the share of the final selling price that is captured by a particular actor in the value chain and Marketing margins were computed for producers, collectors, wholesalers and retailers. In the chain, wholesalers had the highest share of market margin (38.2) and profit margin (42.5\%). Compared to farmers, traders' (collectors, wholesalers and retailers) operating expense is less than half but their profit margin is more than that of farmers.

Traders by buying from the farmers and selling to consumers, traders took $84.5 \%$ of the total profit margin.

Table7: Cabbage marketing costs and benefit shares of male actors

\begin{tabular}{lllllll}
\hline Cost items (ETB(Qt) & Male actors & & & \\
& Produc & Collector & Wholesaler & Retailer & Sum \\
& ers & s & s & s & \\
\hline Purchasing price & - & 250 & 350 & 480 & 1130 \\
Production cost & 195 & - & - & $\cdot$ & 195 \\
Marketing costs & & & & & \\
Transport & 10 & 10 & 5 & 5 & 30 \\
Packing material & 6 & 6 & 6 & 6 & 24 \\
Loading unloading & - & 10 & 10 & 10 & 30 \\
Tax & - & - & 2 & 2 & 4 \\
Total marketing cost & 16 & 26 & 23 & 23 & 88 \\
Total cost & 211 & 26 & 23 & 23 & 283 \\
Selling price & 250 & 350 & 480 & 535 & 1615 \\
Market margin & 55 & 100 & 130 & 55 & 340 \\
\% share of margin & 16.2 & 29.4 & 38.2 & 16.2 & 100 \\
Profit margin & 39 & 74 & 107 & 32 & 252 \\
\% share of profit & 15.5 & 29.3 & 42.5 & 12.7 & 100
\end{tabular}

Source: own computation from survey result, 2018. 
Table8: Cabbage marketing costs and benefit shares of female actors

\begin{tabular}{llllll}
\hline Costitems (ETB/Qt) & \multicolumn{5}{c}{ Female actors } \\
\cline { 2 - 6 } & Producers & Collectors & Wholesalers & Retailers & Sum \\
\hline Purchasing price & - & 250 & 350 & 480 & 1130 \\
Production cost & 131.8 & - & - & - & 195 \\
Marketing costs & & & & & \\
Transport & 10 & 10 & 5 & 5 & 30 \\
Packing material & 6 & 6 & 6 & 6 & 24 \\
Loadingunloading & - & 10 & 10 & 10 & 30 \\
Tax & - & - & 2 & 2 & 4 \\
Total marketing cost & 16 & 26 & 23 & 23 & 88 \\
Total cost & 147.8 & 26 & 23 & 23 & 283 \\
Selling price & 250 & 350 & 480 & 535 & 1615 \\
Market margin & 118.2 & 100 & 130 & 55 & 403.2 \\
\% share of margin & 29.3 & 24.8 & 32.2 & 13.7 & 100 \\
Profit margin & 102.2 & 74 & 107 & 32 & 315.2 \\
\hline Source: & & & & & \\
\end{tabular}

Source: own computation from survey result, 2018.

\section{Cabbage Marketing Margin}

Table 9 indicates that marketing margins of cabbage in the seven channels for each group of market player. GMMp, GMMc, GMMr and GMMw are gross marketing margins of producers, collectors, retailers and wholesalers, respectively. NMMc, NMMr and NMMw are net marketing margins of collectors, retailers and wholesalers, respectively. Gross Marketing Margin (GMM) is the difference between what the consumers paid for the commodity and what the farmers received. It is also calculated as the percentage share received by each marketing intermediaries. There is a strong cumulative effect on the marketing margin resulting from the increasing number of intermediaries involved in marketing process. Total gross marketing margin was high in channel $\mathrm{V}$ and VII which is $50 \%$ and $53.3 \%$, respectively low in channel III in which $12.5 \%$ of Total Gross Marketing Margin (TGMM) added to cabbage price in the channel when it reached the final consumers. Retailers have got the highest GMMr in channel V and II whereas wholesalers have got the lowest GMMw in channel VII. Net marketing margin was computed from the difference between percentage shares of gross marketing margin and total marketing costs as the percentage of retail prices in the channels. Accordingly, channel VI was the highest NMM, which constituted for $40.2 \%$ of net income. The minimum NMM was taken in channel II, which constituted for $7.1 \%$ of NMM in the channel. Along the channel VII, the highest share of NMM (20\%) went to wholesalers and the lowest to retailers. These marketing margins difference among market chains and actors were evidence for the existence of market inefficiency, which arose due to differences in marketing costs and price difference between producers and consumers. There was relatively fair distribution of NMM among actors in the channels VI. Table 9: Marketing margins of cabbage

\begin{tabular}{llllllll}
\multicolumn{7}{l}{ Table 8: Marketing margins of cabbage } \\
\hline Marketing margin & I & II & III & IV & V & VI & VII \\
\hline TGMM & 0 & 33.3 & 12.5 & 30 & 50 & 44.4 & 53.3 \\
GMMp & 100 & 66.7 & 87.5 & 70 & 50 & 55.6 & 46.7 \\
GMMc & - & - & - & - & 20 & 22.2 & 18.7 \\
GMMr & - & 33.3 & - & 20 & 30 & & 25.3 \\
GMMw & - & - & 12.5 & 10 & - & 22.2 & 9.3 \\
Total NMM & & 7.1 & 26.75 & 27.8 & 21.2 & 40.2 & 39.78 \\
NMMc & - & & & & 14.8 & 16.4 & 13.8 \\
NMMr & - & 7.1 & & 6.4 & 6.4 & & 5.98 \\
NMMw & - & & 26.75 & 21.4 & & 23.8 & 20 \\
\hline
\end{tabular}

Source: own computation from survey result, 2018.

\section{Onion market performance}

\section{Marketing costs and benefit share of actors in onion value chain}

Table 10 and 11 indicates different types of marketing cost related to the transaction of onion by producers, wholesalers and retailers and the benefit share of each marketing actors. Production costs such as seeds, fertilizers and labour were computed. As most of households used their own family labour, oxen and land, opportunity costs were used to compute costs of production. Accordingly, average cost of onion production for sample producers was $480 \mathrm{ETB} / \mathrm{Qt}$. Actors in onion value chain incurred marketing costs for transportation, packing, loading and taxes. Marketing margin used to measure the share of the final selling price that is captured by a particular actor in the value chain and Marketing margins were computed for producers, wholesalers and retailers. In the chain, producers had the highest share of market margin (51) and profit margin (51.6\%) this is because of small number of value chain actors in the chain as compare with others vegetables and in study areas onion is common with its leaf, consumers prefer to buy onion which have many leaf and fresh.

Table 10: Onion marketing costs and benefit shares of male actor 
International Journal of Engineering Applied Sciences and Technology, 2020

Vol. 4, Issue 10, ISSN No. 2455-2143, Pages 287-298

Published Online February 2020 in IJEAST (http://www.ijeast.com)

\begin{tabular}{|c|c|c|c|c|}
\hline \multirow[t]{2}{*}{ Cost items (ETB/ Qt) } & \multicolumn{4}{|l|}{ Male actors } \\
\hline & Producers & Wholesalers & Retailers & Sum \\
\hline Purchasing price & - & 1000 & 1200 & 2200 \\
\hline Production cost & 480 & - & - & 480 \\
\hline \multicolumn{5}{|l|}{ Marketing costs } \\
\hline Transport & 20 & - & - & 20 \\
\hline Packing material & 12 & 12 & 12 & 36 \\
\hline Loading/unloading & 10 & 10 & 10 & 30 \\
\hline $\operatorname{Tax}$ & - & 4 & 4 & 8 \\
\hline Total marketing cost & 42 & 26 & 26 & 94 \\
\hline Total cost & 522 & 26 & 26 & 574 \\
\hline Selling price & 1000 & 1200 & 1500 & 3,700 \\
\hline Market margin & 520 & 200 & 300 & 1020 \\
\hline$\%$ share of margin & 51 & 19.6 & 29.4 & 100 \\
\hline Profit margin & 478 & 174 & 274 & 926 \\
\hline$\%$ share Profit & 51.6 & 18.8 & 29.6 & 100 \\
\hline
\end{tabular}

Source: own computation from survey result, 2018.

Table 11: Onion marketing costs and benefit shares of female actor

\begin{tabular}{|c|c|c|c|c|}
\hline \multirow{2}{*}{$\begin{array}{l}\text { Cost items } \\
\text { (ETB/ Qt) }\end{array}$} & \multicolumn{4}{|c|}{ Female actors } \\
\hline & Producers & Wholesalers & Retailers & Sum \\
\hline Purchasing price & - & 1000 & 1200 & 2200 \\
\hline Production cost & 406.95 & - & - & 406.95 \\
\hline \multicolumn{5}{|l|}{ Marketing costs } \\
\hline Transport & 20 & - & - & 20 \\
\hline Packing material & 12 & 12 & 12 & 36 \\
\hline Loading/unloading & 10 & 10 & 10 & 30 \\
\hline Tax & - & 4 & 4 & 8 \\
\hline Total marketing cost & 42 & 26 & 26 & 94 \\
\hline Total cost & 448.95 & 26 & 26 & 500.95 \\
\hline Selling price & 1000 & 1200 & 1500 & 3,700 \\
\hline Market margin & 551.05 & 200 & 300 & 1051.05 \\
\hline$\%$ share of margin & 52.5 & 19 & 28.5 & 100 \\
\hline Profit margin & 509.05 & 174 & 274 & 957.05 \\
\hline$\%$ share Profit & 53.2 & 18.2 & 28.6 & $1 \mathrm{po}$ \\
\hline
\end{tabular}

Source: own computation from survey result, 2018.

\section{Marketing margins of onion}

Table 12 indicates that marketing margins of onion in the four channels for each group of market player. GMMp, GMMr and GMMw are gross marketing margins of producers, retailers and wholesalers respectively. NMMr and NMMw are net marketing margins of retailers and wholesalers, respectively. The total gross marketing margin (TGMM) is the highest in channel IV which is 40 $\%$. Retailers have got the highest GMMr in channel IV whereas wholesalers have got the lowest GMMw in channel III. The Net Marketing Margin was computed for each actor in the channels by subtracting total marketing costs (as the percentage of retail price in each channel) from gross marketing margin of each actor. Accordingly, channel IV had the highest NMM, which constituted for $29.9 \%$ compared with $14.5 \%$ of channel III. Marketing margins difference between market channels and among actors were evidence for the existence of market performance. These differences arose due to marketing costs and prices added between producers and consumers.

Table 12: Marketing margins of onion.

\begin{tabular}{lllll}
\hline Marketing margin & I & II & II & IV \\
\hline TGMM & 0 & 15.4 & 16.7 & 40 \\
GMMi & 100 & 84.6 & 83.3 & 60 \\
GMMir & $\cdot$ & 15.4 & $\cdot$ & 20 \\
GMMiv & $\cdot$ & $\cdot$ & 16.7 & 20 \\
Total NMM & & 21.07 & 14.5 & 29.9 \\
MMMr & $\cdot$ & 21.07 & $\cdot$ & 18.3 \\
NMMiv & $\cdot$ & $\cdot$ & 14.5 & 11.6 \\
\hline
\end{tabular}

Source: Own computation from survey result, 2018.

\section{Production and marketing opportunities and challenges of vegetables}

Different production and marketing opportunities and constraints were identified from different actors through group discussion in study areas.

\section{Production constraints}

There are factors that affect the production of vegetables products in the study area. The data gathered from focused group discussion indicated that seed shortage, pesticide shortage, diseases, insects, frost and wild animals attack as major constraints of vegetables production. 


\section{International Journal of Engineering Applied Sciences and Technology, 2020 \\ Vol. 4, Issue 10, ISSN No. 2455-2143, Pages 287-298 \\ Published Online February 2020 in IJEAST (http://www.ijeast.com)}

\section{Limited access and supply of inputs for vegetable production}

The most important inputs for vegetable production are improved seeds, fertilizers, pesticide/herbicides, irrigation water, Research and extension services, information and technological support are important for higher yields. However people who participate in FGD replied limited access and supply of inputs as their production problem this is caused mainly due to absence of vegetable seed distributing agency, shortage of supply, high input price and delay in input supply because of weak chain input supplier especially for improved seeds in case of this producer buy seed from market/ unknown sources it have germination problem, inadaptable with environment, poor quality and diseases resistance problem and sometimes informal seed supplier were sale fake seed e.g. Kale seed as cabbage and other constraints which hinder producers are limited mood of extension service and male centered extension service, limited service regarding pre/postharvest technology farming advice.

\section{Diseases and pests}

Participants of FGD replied that unavailability of pesticide and herbicides mainly create these problems in addition to the problem of accessing to improve and diseases resistance seeds. This shows most farmers are using poor quality seeds and unknown source because high quality seeds are often not available at planting time and too expensive. The other reason for this problem is the problem of farm management skill. Inadequate farmer skills and knowledge on improved technologies creates such problems. This is mainly related with poor extension service in the study areas.

\section{Natural factors}

Participants of FGD and KII mention that Natural factors such as frosts, rainfall, and flood are often beyond the control of farmers.

\section{Wild animals attack}

Participants of FGD in four kebeles replied that wild animals attack vegetables especially ape and monkey are beyond the control of farmers. In case of this some farmers shift to khat production.

\section{Production opportunities}

Opportunities that were identified in study areas; Availability of irrigation water, districts are very suitable to produce vegetable products (favorable land and climate, Government suitable agricultural policies(enabling policy environment),availability of $\mathrm{NGO}$ (wetland) that provide production inputs to the farmers(especially for women's )and better infrastructure facilities like roads, telecommunication, power supply and financial institutions are the infrastructural advantages that facilitate the production and marketing of vegetables in the study areas.

\section{Marketing constraints}

Information from FGD showed that the major vegetable marketing constraints are non-availability of market place to sell vegetable products, low price of product, low quality product that cannot meet consumers demand and perishability. In addition all traders engage in vegetables value chain mention that; the problem of supply shortage, lack of storage facility and lack of support from concerned bodies

\section{Marketing opportunities}

On the other hand high market demand for vegetables throughout the year, increasing number of buyers, growing price/ increasing price were some of the opportunities of vegetables by most of the producers.

\section{CONCLUSION}

This study was aimed at analyzing gender disaggregated vegetable value chain in Yayu and Hurumu district of southwest Ethiopia. The specific objectives of the study include examine the role of gender in the production and marketing, assess distribution of benefit among actors in vegetable value chain and identify challenges and opportunities of vegetable production and marketing in the study areas. The data were generated from both primary and secondary sources. The primary data were collected from individual interview using semi-structured questionnaire and checklist. The primary data for this study were collected from 117 randomly selected households, 37 traders and 31 consumers from Yayu and Hurumu districts. The analysis was made using descriptive statistics and econometric model using SPSS version 20 and STATA version 13. All the sampled households were vegetable producers.

Men and women are involved in different vegetables production and marketing activities. Marketing of vegetables where $88 \%$ were done by women and women's are dominantly participate in retail market. The study result shows that female retailers were unable to engage in wholesale since they lacked the necessary financial capital for buying the larger volumes required for this activity and their lack of confidence and business skills as the main reasons for not growing their business. Both these cultural and profit-making perceptions require untangling in future research undertakings so as to come up with appropriate interventions. 


\section{International Journal of Engineering Applied Sciences and Technology, 2020 \\ Vol. 4, Issue 10, ISSN No. 2455-2143, Pages 287-298 \\ Published Online February 2020 in IJEAST (http://www.ijeast.com)}

The higher difference prevailed in prices between producers and traders shows that there was little assistance of farmers due vegetables production inputs. The low percentage share of producers from vegetables value chain especially in cabbage market needs intervention to improve the gain of farmers by accessing them to higher markets. Further, the higher price changes exhibited between producers and consumers' shows that there was lower access that consumers to purchase directly from farmers; hence urban consumers were directly purchasing from retailers paying higher prices.

Women found to be playing important role in sustaining vegetable value chain, from early planting to marketing. Their decision to produce vegetables at least homestead reveals their participation in vegetables value chain in the study area. However, an identified factors which inhibit their extent of participation and role need to be intervened.

\section{ACKNOWLEDGEMENT}

I would like to praise the everlasting Father and the Prince of love and peace the Almighty God who always let the bulk of unfinished work to be completed at a moment and thank NutriHAF project for financial support by the German Federal Ministry of Food and Agriculture based on the decision of the parliament of the Federal Republic of Germany. In addition, I would like to express my sincere appreciation and gratitude to the RUFORUM for having offered me especially good opportunity to the accommodation and different computer software training.

\section{REFERENCES}

[1] Anteneh,B.(2008)GenderandAgriculturaProduction in Ethiopia: The Case of Gozamen Woreda, Amhara Region. Addis Ababa: Addis Ababa.

[2] CentralStatistical Agency(CSA).(2015).Annual Agricultural Sample Survey (Meher season) report on Crops Area and Production. Addis Ababa, Ethiopia.

[3] Durr, J. and Teshome, A. (2016). Nutrition-sensitive value chains: the case of vegetables in Yayu biosphere reserve, Ethiopia.

[4] Emana, B. and Gebremedihin ,H . (2007). Constraints and opportunities of horticulture production and marketing in Eastern Ethiopia. Norway.: Dry Lands Coordination Group Report No 46. Grensen 9b.

[5] Ethiopia Investment Commission, EIC. (2015). A Preferred Location for Foreign Direct Investment. Addis Abeba : Federal Democratic Republic of Ethiopia (FDRE.
[6] Mendoza, G. (1995). A prime on market channels and margins. In G.J. Scott. Prices, Products, and People: Analyzing Agricultural Markets in Developing Countries. Lynne Reinner Publishers, Boulder, London. 257- 275.

[7] Plan for Accelerated and Sustained Development to End Poverty, PASDEP.(2005). Ethiopia: Building onProgress . Addis Abeba.

[8] Tegegn., A. (2013). Value Chain Analysis of Vegetables: The case of Habro and Kombolcha Woreda Oromiya Region, Ethiopia. MSc. Thesis presented to the School of Graduate Studies of Haramaya University, Haramaya, Ethiopia . Haramaya: Haramaya universiy.

[9] Yamane, T. (1967). Statistics, Introductory Analysis, 2nd Ed. New York: Harper and Row.

[10],YayuW.(2016)https://en.wikipedia.org/wiki/Yayu_ (woreda).

[11] United Nations Development Program UNDP. (2015).Ethiopia: Quarterly Economic Brief. Third Quarter. 